\title{
The Politics of Architecture and Urbanism in Postcolonial Lagos, 1960-1986*
}

\author{
DANIEL IMMERWAHR \\ Department of History, University of California, Berkeley
}

This is a preprint of an article to appear in the Journal of African Cultural Studies 19:2 (December 2007). It will be available online at http://journalsonline.tandf.co.uk/

After independence, the Nigerian government faced a number of choices about how to manage its urban environment, particularly in Lagos, $\mathrm{Ni}$ geria's capital. By favoring a program of tropical modernist architecture for its prestige buildings in Lagos and British New Town style for its housing estates there, the government sought to demonstrate both its independence from European culture and its ability to perform the functions of a modern state. And yet, the hopes of government officials and elites for Lagos were frustrated as Lagosians, in response to new economic and demographic forces, shaped a very different sort of city from below. The Nigerian government's retreat to Abuja and its abandonment of Lagos mark the failures of urban policymaking in Nigeria.

\section{Colonial and Postcolonial Cities}

In the past twenty-five years, historians have devoted a good deal of attention to the spatial aspects of colonial rule. The "colonial city" has emerged as an archetype fundamentally different from the metropolitan city. Anthony King's pioneering work $(1976,1990)$ emphasized the importance of the world economy in determining the shape of colonial cities, and a number of case studies, including those of Janet Abu-Lughod (1980), Gwendolyn Wright (1991), Anja Nevanlinna (1996), and Zeynep Çelik (1997) have further explored the consequences of colonial urban policy. In their work, the colonial city is depicted as a dual city-one part composed of quarantined governmental areas featuring European architecture and urban planning and the other of native quarters, which were either subject to heavily restrictive preservation laws or else, as in the case of Lagos, ignored entirely.

Less has been said about the fate of colonial cities after independence. In part, that absence might be chalked up to the fact that there is disappointingly little to say. In general, the apartheid that marked colonial ur-

\footnotetext{
* I would like to thank John Lonsdale, Gwen Wright, Abena Osseo-Asare, Dk OsseoAsare, Jon Cole, and Ola Uduku for their help with various aspects of my research.
} 
banism can be seen just as clearly in postcolonial cities. Gwendolyn Wright's summary judgment - that "while African cities have grown exponentially since independence, colonial patterns of land use, restrictions, neglect, and adaptation remain in evidence"-is largely the consensus view (2002:225). A cursory examination of Lagos bears out that conclusion. Lagos's downtown hotels, sanitized government areas, and upscale mansions contrast starkly with its peripheral slums and chaotic markets, which fall almost entirely outside of the purview of the state. So extreme is the contrast between the controlled and secure space intended for use by the ruling classes and the uncontrolled space left over for the rest that the renown architect Rem Koolhaas (2001) has recently seized upon Lagos as an emblem for what he believes to be the polarized and commercialized world of the future. Class segregation may well have replaced colonial segregation in modern-day Lagos, but the legacy of the dual city quite clearly abides.

Simply to say, however, that post-independence Lagos resembles colonial Lagos is insufficient. Although we can still speak of a "dual city," we must also recognize that Nigerian independence in 1960 marked a significant change in governmental policies concerning the city. First, a new architectural image for Lagos was actively sought. The construction of new buildings - buildings that did not bear the mark of a colonizing power-became an important national priority. Second, the Nigerian government gradually assumed responsibility for providing housing for the urban population. The old colonial practice of building accommodation for foreigners and government officials while leaving local laborers to fend for themselves was, for obvious reasons, no longer appropriate. Both through regulation and through direct actions like construction and slum clearance, the government took up a much more active role in determining the built environment of Lagos, even if it remained relatively ineffective when compared to the governments of first-world countries.

At the same time as the government expanded its sphere of activity in the organization of space, the economic and demographic forces continued to draw migrants into Lagos in search of work. The population of greater Lagos rose from 1.14 million in 1963 to 2.55 million in 1976 and up to 4.07 million by 1982, with many of the newcomers squatting or living in illegal housing (Adisa 1994). Thus, as the Nigerian elite, newly concerned with urban housing, attempted to build and maintain sanitized, European-style public areas, Lagosians found themselves participating in and advocating for other urban forms - shantytowns, informal markets, streetside production, and unregulated, mixed-use spaces.

Those two trends - the government's new responsibilities in matters of architecture and urbanism and the unplanned growth of shantytowns and an informal economy-were the motors driving the development of Lagos's architectural and urban forms in the decades after independence. In response, state officials and Lagosians were forced to articulate their own visions for the shape of the city. Through an examination of prestige 
architecture, housing estates, shantytowns, and the new Nigerian capital at Abuja, I will argue that policymakers in independent Nigeria had a bifurcated architectural vision for Lagos: they favored tropical modernism, a bold hybrid idiom, as the official style of government offices and major downtown buildings while at the same time preferring by-thebook copies of European residences for government housing estates. The inhabitants of Lagos, by contrast, responded to the demands of low wages and a burgeoning workforce by favoring built forms that allowed them to maintain a complex informal economy and to keep alive some aspects of indigenous building traditions. All of those visions for postcolonial Lagos, however, were constrained by larger economic, demographic, and historical forces. This article will show how differing visions informed policies and actions around prestige architecture, housing estates, and shantytowns. Finally, it will consider the transfer of the Nigerian capital from Lagos to Abuja as an emblem of the failures of those visions.

\section{Tropical Modernism}

To understand the Nigerian elite's hopes for Lagos, one must start with tropical modernism, an architectural idiom developed shortly after the Second World War by architects building in British West Africa, particularly Nigeria. An emphatically modern style, tropical modernism had been adapted for warmer climates from the International Style associated with Le Corbusier, Ludwig Mies van der Rohe, and Walter Gropius. As such, it stood in stark contrast to the colonial architecture that had until the war been the only form of European-built architecture in Lagos. Verandahs, baroque ornamentation, and classical columns were replaced with rougher, geometric forms of concrete, steel, and glass. The new style quickly won favor among both corporate clients and the independent government as the face of the new Nigeria. By the end of the 1960s, Lagos's central business district had been almost entirely rebuilt in its image. ${ }^{1}$

The principal motor behind this new idiom was a group of mostly British architects trained in London. That group gained its first major institutional foothold in 1953, when Adedokun Adeyemi, a Nigerian student at the Architectural Association (AA), set up a conference on the subject of tropical architecture. Adeyemi was concerned that the training offered by the AA prepared students inadequately for the challenge of building in Britain's overseas colonies, where built forms designed for a temperate European climate were unsuitable. In 1954, the AA established a Department of Tropical Architecture. A number of British students and a small handful of African students took the lessons they learned in London and moved in the late 1950s and early 1960s to West Africa, particularly to Lagos.

\footnotetext{
${ }^{1}$ Tropical modernism has received a great deal of interest lately. The best overviews of tropical modernism in West Africa are Hannah Le Roux's work (2003, 2004b).
} 
For British architects, the chance to work in West Africa meant a chance to try out bold new forms. Africa had already loomed large in the cultural imagination of European architects as a space for experimentation. According to architectural historian Gwendolyn Wright (2002:225), colonial Africa served as an ideal "laboratory for the West," because architects could "explore new models, unencumbered by the constraints of democratic politics or shared cultural norms." Although independence ostensibly brought democratic representation with it, opportunities for unchecked architectural experimentation still abounded. In their foundational treatise on tropical architecture, Maxwell Fry and Jane Drew mentioned "how invigorating it has been for us as architects working in England to shake free from the crippling mental state brought about by too great a reverence for habits and customs which have outlasted their time" (1964:18). "This area has been called the 'Architect's Paradise,", one British architect (Mark 1964:52) explained, "with the implication that everything and anything is allowed."

What can be said about tropical modernism as a form of architecture? The first thing that must be mentioned is its debt to modernist architects in Europe, especially to Le Corbusier. Fry and Drew, the movement's principal theorists, made their debt to Le Corbusier explicit in their writings on the subject and later went to work for him on Chandigarh in the Punjab. Even when intellectual ties to European modernism were not explicitly mentioned, they were blatantly exhibited in the buildings themselves. Slim, streamlined slabs of reinforced concrete with unadorned faces - the signs of modernism in Europe-were also the markers of tropical modernism. It was no surprise, then, that the Nigerian Institute of Architects, formed by Nigerian students who would later go on to become some of the top architects in the country, was established in 1960 not in Lagos, but in London.

And yet, architects working in Nigeria were not content merely to copy European models. They insisted, time and again, that their field of operation required important architectural adaptations, most notably to Nigeria's climate. It would be hard to overestimate the importance of climate as a category of thought for architects in Lagos. Despite the many distinctions between Western Europe and West Africa that they might have emphasized - in economy, society, religion, culture, and history-it was climate that served as the sign of architectural difference. The Department of Tropical Architecture at the AA in London, where Lagos's most influential architects studied or taught, as it name suggests, focused on West Africa principally as a novel climate demanding new architectural solutions. The two principal theoretical works of the movement, Fry and Drew's Tropical Architecture in the Dry and Humid Zones (1964) and Otto Koenigsberger's two-volume Manual of Tropical Housing and Design (1974), both focused a great deal of attention on technical questions of ventilation, shade, humidity, and so forth. Although a few architects working in Lagos were interested in architecture 
as a cultural intervention, climate remained the most written-about aspect of Lagosian architecture - the topic through which all other topics were approached. $^{2}$

The task of adapting a European architectural oeuvre to a hot and humid climate stimulated some innovations in the form of building. Most importantly, ventilation became a minor obsession of the new style. It is worth noting that ventilation is not the only way of dealing with a hot climate, and in fact the traditional Yoruba adaptation to heat was to build small, dark rooms allowing very little light inside (Krapf-Askari 1969:58). Tropical modernists, however, preferred to make their spaces as open as possible. Fry and Drew (1964:63) fantasized about supplanting Mies van der Rohe's famed house of glass with a "house of air": a large overhanging roof with only mosquito nets and a few structural supports in the place of walls. In their design for the library of the West African University College at Ibadan, a key icon of tropical modernism, they erected an enormous grille of concrete and fly gauze to protect the building from heat and insects. The design was so effective, recalled Fry (1962:30), that "visiting Americans ask what kind of air-conditioning is being used." The grille, celebrated both for its ability to cool and for its rough-hewn appearance, was subsequently copied by other architects throughout West Africa. Of course, Fry and Drew's work was imitated as much for its style as its "solution" to climatic problems. As one British architect (Mark 1964:52) working in Nigeria wrote: "Under the pretext of 'adaptation to climatic conditions,' architects have let fly with all the clichés, gambits and stylistic treatments which restrictions and considerations of public taste would not allow them to do in Europe."

Another element of West African building developed by Fry and Drew, although perhaps a less substantial one, was the introduction of traditional or handicraft art into the modern buildings, most often in the form of murals, mosaics, carved wooden doors, or statues. Inclusion of art into modernist projects became the standard, and most new corporate buildings made some sort of gesture, however slight, toward making their buildings look more "African." Although from an architectural standpoint, the inclusion of Nigerian art and handicraft work may have been little more than cheap pandering, its importance for artists in Lagos was not trivial. Because Lagos had no major art gallery, hotels and other prestige projects such as the twenty-five-story Independence Building were among the principal exhibitors and patrons of contemporary art. "Many Nigerian artists have at one time or the other done work on buildings," explained a young Lagosian muralist (Grillo 1968:3), adding that "a few are now specialising in designing for architecture."

The largely tokenistic incorporation of local art into prestige projects, however, was the extent of tropical modernism's cultural accommoda-

\footnotetext{
${ }^{2}$ Seeing them as more than just aesthetic or technical, Hannah Le Roux (2004a) has offered an interpretation of the climatic adjustments of modernist architecture made by architects working in the tropics in terms of the politics of colonialism.
} 
tion to its locale. Once tropical modernism had been seized upon as the national idiom, there was surprisingly little interest on the part of Nigeria's architects in developing it or adapting it to incorporate indigenous traditions or culture. West African Builder and Architect featured only the occasional article dealing with the cultural questions raised by a colonial legacy. One of the few architects who did express strong interest in vernacular architecture, Alan Vaughan-Richards, found himself by and large out of step with his colleagues. At a design conference attended by the majority of important Lagosian builders, VaughanRichards broke from the unspoken tenets of tropical modernism by suggesting, along with Oluwole Olumuyiwa, that architects should move away from the geometric Corbusian ideal toward curved and molded forms modeled on Yoruba mud architecture - an innovation made possible by the development of computers (Vaughan-Richards 1967a, 1967b; West African Builder and Architect 1965a, 1965b; Le Roux 2004b). Although a few audience members approved, a greater number opposed it. W. J. Kidd, dean of the faculty of Architecture at Ahmadu Bello University, Nigeria's only architecture faculty, spoke for the majority when he protested that although mud architecture could be appreciated for its aesthetic value, any attempt to actually integrate it into functional buildings would be disastrous - too large a shift from current practice. "Even if we do not like the International Style," Kidd declared, "we have got it" (quoted in West African Builder and Architect 1967:97). Kidd's rejection of Vaughan-Richards and Olumuyiwa's proposal expressed the general consensus among Nigerian architects that while the business of architecture may be to establish an important identity for Nigeria, it could do so only by looking forward to a modernist future, with no real engagement with local history or culture.

\section{Slum Clearance and Housing Estates}

Questions of whether and how new buildings erected in Lagos after independence allowed architects and their clients to assert a new symbolic identity for Nigeria were of great importance to local elites, but for the majority of Lagosians expensive government buildings, embassies, and corporate housing meant much less. Despite its rhetoric about changing the face of Africa, tropical modernism in Lagos was limited to the central business district and to a few buildings scattered elsewhere throughout the city. And when it came to the sorts of buildings that might be of importance to non-elite Lagosians - housing estates and apartment complexes-tropical modernists had conspicuously little to say. Fry and Drew largely ignored the subject of housing in their handbook Tropical Architecture in Dry and Humid Climates. Of the few housing projects they did mention, not a single one was located in their own base of operations, West Africa.

The omission was not accidental. Planning and housing provision in Lagos operated on a different track from prestige architecture. Although 
official reports occasionally mentioned the need for culturally sensitive dwellings, the government made no real attempt to distance itself from colonial blueprints for housing and the planning of residential estates. The considerable investment it made in housing was channeled exclusively into European-style projects. But building British New Towns in Milton Keynes was different from building them in Lagos. Lagosian planners had something else to contend with that British planners did not: a postcolonial economy.

Although Nigeria had known urbanization long before colonialism, housing per se was never a concern in Nigeria until the industrial economy pulled large numbers of workers into the urban areas in the twentieth century (Okoye 1990:73). The colonial government, however, did little to meet the needs of a growing urban population. Unlike colonial cities in Australia or the Americas, where a settling population developed planned cities, the built environment of Lagos was for the most part touched by colonialism only indirectly, through economic forces rather than direct legislation. The exception to that laissez-faire policy, of course, was the European residential areas themselves, which were laid out along broad avenues and segregated from native quarters. Following the principles of segregation established by Lord Lugar, colonial governor of Northern Nigeria and then of the entire country for the first two decades of the twentieth century, European residential areas were surrounded by building-free zones at least 440 yards wide, that ostensibly being greater than the distance a disease-bearing mosquito could fly (Home 1983:166).

The colonial government's sole interest in native space was the threat it might pose, from disease or fire, to European space. Thus, the only significant building regulations pertaining to native houses were those forbidding dangerously inflammable construction materials, most notably thatched roofs - an understandable concern, as Lagos had been the site of as many as forty major fires between 1859 and 1892 (Mabogunje 1968:117). British interest in hygiene led to the widening of a few streets and the reclamation of some swampland, but it was only in reaction to an outbreak of plague in 1924 that the government established a planning authority, The Lagos Executive Development Board (LEDB), launched in 1928. For the next thirty years, though, the LEDB served only to protect Europeans from risk and to facilitate industry and port trade; the development of infrastructure for its own sake was never a priority.

In the years leading up to independence, the government's attitude toward urban space began to change. Lagos was no longer just a cash source from which an extractive government could fill its coffers, but was soon to be the capital city of the most populous independent nation in Africa. As capital cities go, however, Lagos was beginning to look like an embarrassment. "For years the slums of Lagos have been notorious," reported the West African Review, "and it has been truly said that some of the lean-to-shelters occupied by large and poverty-stricken fami- 
lies in Lagos are not fit to house sheep and goats, much less human beings" (James 1959:8-9). Noting that Lagos "is the mirror through which foreigners make their initial appraisal of Nigeria," the Minister of Lagos, Alhaji Yar Adua, declared to the House of Representatives that central Lagos was "humiliating to any person with a sense of national pride" (Marris 1962:vii).

It was with these concerns in mind that the LEDB initiated a massive slum clearance programme, begun in 1955 and extending three years into the independence period, to clear seventy acres of land on Lagos Island. In addition to sanitizing central Lagos, the slum clearance scheme paved the way, literally, for the development of Lagos's Central Business District along the Marina, Broad Street, and Nnamdi Azikiwe Street. In all, roughly twenty thousand Lagosians were displaced. The LEDB stated its intention to sell the cleared land back to its former residents, but very few ended up returning, as the cleared land was more expensive per acre and sold primarily in large - and prohibitively expensive-parcels (Marris 1962:85; Peil 1991:168).

In order to house the "temporarily" displaced Lagosians, the LEDB set up a housing estate far north on the mainland named Surulere, after the Yoruba phrase meaning "patience is rewarded." The Surulere estate is worthy of some attention, both because it was the site of continued government investment throughout the decades after independence and because it set the pattern for a number of subsequent public housing schemes - including the Dolphin Scheme, the Ogba Scheme, and Festac Village.

Surulere was built, as the European residential areas of Ebute-Metta and Yaba South had been built earlier in the century, on the British Garden City model. It was meant to be a clean, quiet, and spacious enclave removed from the clangor of urban life. As such, it did not look much different - in its plan, at least - from the New Towns of Britain or the automobile suburbs of the United States. Detached homes with garages and blocks of flats (for poorer residents) lined wide streets in zoned residential areas in which any commercial activity was prohibited. The same pattern could be found in all subsequent government-built housing estates. Even the command in the 1980 National Housing Policy that lowcost housing should reflect "Nigerian variations, climate, cultural practice ... and social conditions" meant little more in practice than the buildings were slightly better ventilated than their British prototypes (quoted in Amdii 1993:152).

The lack of architectural adaptation to climate and culture by architects putting up housing seems at first puzzling, especially in the face of the government's enthusiastic patronage of tropical modernism for its prestige buildings. Even more puzzling, the Senior Architect for the LEDB in the 1960s was none other than Adeokun Adeyemi, the Nigerian student whose conference in London on tropical architecture provided the impetus for the foundation of the Department of Tropical Architec- 
ture at the AA. Adeyemi was also one of the three founders of the Nigerian Institute of Architects. Better credentials as a tropical modernist could hardly be asked, and yet his work for the LEDB bore no stamp of his training as a modernist. His contributions to the Board's housing designs meant little more than that the new houses put up would be, in the LEDB's words, "strictly in keeping with modern taste"- the word "modern" here signaling kitchens and garages, not cantilevered slabs of reinforced concrete (Lagos Executive Development Board 1963:19).

The key to understanding the seemingly contradictory desires of the elite Nigerians and the government to create a new architectural idiom for prestige architecture while ignoring that idiom entirely when it came to housing is the recognition that they in fact had a dual vision for Lagos's postcolonial image. On the one hand, prominent buildings on Lagos Island would suggest a rebellion from the colonial past, while, on the other, governmental estates featuring the same modern houses that one could see in developed nations would suggest the power and stability of the new Nigeria. Indeed, the government was in no way ashamed of its European-style housing estates, but eagerly put them on display. The LEDB conducted frequent tours of its estates for visiting notables (including Harold Macmillan and Leopold Senghor), and, during Lagos's Independence Exhibition in 1960, constructed a special cinema for hourly shows of its film The Changing City (Lagos Executive Development Board 1961:48). At FESTAC '77, an ambitious Pan-African exposition held in Lagos and funded by oil money, festival planners dedicated themselves to the task of reclaiming a forgotten precolonial cultural legacy, but the estate in which visiting dignitaries were housed was, as a UN report put it, "designed and built on typical European new towns' standards" (quoted in Awotona 1981:121; see also Apter 2005:49-50). Government estates, modern if not modernist, highlighted the nation's stability and its ability to provide.

The Nigerian government's decision to house its citizenry in European-styled estates was by no means inconsequential. The Garden City model used for colonial Government Reservation Areas and for British New Towns was explicitly designed for a certain type of subject: an upwardly mobile worker for whom daily toil in a factory would be punctuated by evenings and holidays spent in self-improvement and leisure in a hygienic, quiet suburb (Fishman 1999). In many ways, that model lifestyle was a poor fit for the lives of low-income Lagosians, and, consequently, the estates themselves failed to provide for the needs of their residents.

An important distinction setting the Lagosian economy (and indeed many urban economies in developing countries) apart from the metropolitan economies of cities like London has been the high prevalence of informal economic interactions taking place outside of established shops in fixed geographic locations. In a 1976 study commissioned by the UN, Olanrewaju J. Fapohunda (1985:5) estimated that the informal sector of 
Lagos comprised about half of employment in the city. The informal sector has fulfilled a number of important functions within the Lagosian economy. It has provided employment in a low-capital environment, where selling from a sidewalk or a private home meant that one need not pay to keep a shop. The low overheads and heavy competition drove prices down, a necessity for people living near or below the poverty line. The easy accessibility of informal selling has also been crucial-many Lagosians have neither the time nor the means to visit shopping centers. For those with long commutes, the ability to bargain for goods while waiting for a bus (or even while onboard the bus) could save precious time (Peil 1991:86-89). Indeed, Fapohunda (1985:90) found that most enterprises were located within walking distance of their customers. Another distinctive characteristic of informal enterprises is that they were more likely to extend credit to customers, thus allowing customers to pay at the end of the month rather than at the time of purchase. The maxim, "no credit, no trade," was repeated often by the informal traders whom Peter Marris interviewed in central Lagos (1962:73). Finally, informal enterprises provide important employment opportunities for women and children. In 1963, 70\% of Lagosian women were involved in petty trading and other related activities (Fapohunda 1985:112).

Thriving as they did on constant traffic and high population density, petty traders found governmental estates inhospitable climates. Peter Marris (1962:97) describes the scene in Surulere in 1962:

Everything about the estate contrasts with central Lagos. The streets are wide and empty, the doors shut, the window slats pulled down. Here and there, a woman has set a tray of cigarettes and provisions on her porch, but there is no bustle of traffic, no one passes by: only once in a while a schoolgirl may pause to buy a pennyworth of toffee. The residents leave early and return late, and their neat homes wear an air of quiet self-containment.

Festac Village, Ogba Estate, and Surulere Estate all featured regulations forbidding commercial transactions within the estates. While these rules were unable to prevent the selling of food, prohibitions against the erection of kiosks and vehicular repair workshops (often very greatly needed) were more easily enforced (Awotona 1981:159, 168-169). In Festac Village, the Federal Housing Administration declared an intention to set up its own kiosks and rent them out, but as of 1981 these had yet to materialize (Awotona 1981:169). Simultaneously, the LEDB and its successors attempted to replace the informal economy with a formal one through the development of shopping complexes to service the housing estates. The predictable result of that prohibition of petty trading and production on the estates was that low-income residents were doubly hurt, both as consumers and, particularly in the case of women, as vendors. 
Another tension between the lifestyle of low-income residents and the organization of housing estates was simply the large distance between most of the estates and the workplaces of the residents. The main housing schemes developed by the Federal Housing Administration during the oil boom were on the northern area of the mainland, a far commute to Lagos Island or Apapa. In part these distances were simply the result of the lack of land in Lagos, but one can also detect a tinge of colonialist apartheid strategies in the distances between government Garden Cities and industrial areas or slums. In 1960, for example, the LEDB proposed a "Green Belt" in Apapa that "was to be a 'buffer' between the low density residential area and the industrial warehouse and medium density areas of Apapa" (Federal Republic of Nigeria 1968:93). Whatever the motivations, the effects of long commutes on estate residents were plain. In Surulere, the first residents found that the cost of transportation added a significant new expense to family budgets - an expense that many simply could not meet (Marris 1962:102-105; Mabogunje 1968:203). The same problem with commuting also prevented many residents from seeing their families often, and in the case of Surulere precipitated the break-up of a number of traditional family meetings (Marris 1962:112).

The initial LEDB slum evacuations met with fierce resistance from those who were to be moved. A riot broke out during one of the first scheduled demolitions, in 1956. Kofo Abayomi, the Chairman of the LEDB in the 1960s, recalled a long spate of anti-LEDB violence, and reported having stones thrown at him and his car demolished by angry slum dwellers (Federal Republic of Nigeria 1968:29). Seeing opportunity, both of the two major political parties in Lagos, the NCNC and the Action Group, took up slum clearance as a partisan issue, each accusing the other of supporting it (Aribiah 1974:5-13; Agbola 1994:91). Scholars, too, took up the fight. Peter Marris's critical study of the Surulere rehousing project, Family and Social Change in an African City (1962), has become one of the few canonical texts in Nigerian urban studies. Following Marris, scholars such as Tade Akin Aina, Margaret Peil, Oberu Aribiah, Olanrewaju Fapohunda, and later Tunde Agbola developed incisive criticisms of the government's housing policies. Lagos Notes and Records (founded in 1967) and African Urban Studies (founded in 1978) took up the task of publicizing these critiques, although there is little evidence that the any government officials paid much attention. As Peil (1991:190) noted, "planning in Lagos is done by politicians, not planners."

Perhaps more important than the stones thrown and books published were the everyday acts of resistance and adaptation on the part of those living in the estates themselves. Although organized protest was never the order of the day, many residents simply ignored ill-fitting government regulations and expectations. For example, whereas Festac's housing units were built upon a European division between sitting rooms and bedrooms, Adenrele Awotona (1981:170-171) found in over $90 \%$ of the 
one-bedroom units he visited that at least one family member slept regularly in the sitting room. In the Lagos State Property Development Corporation's Ogba estate, he frequently found family members sleeping in corridors outside of the flats. Awotona also found many residents in $\mathrm{Og}$ ba estate cooking in the courtyard, selling cooked food in corridors, and washing clothes in the courtyard - activities all forbidden by the management (1981:159). More generally, E. O. Adegite (1996:42) reports that women in housing estates frequently put up illegal trading tents and structures, despite constant enforcement of the rules forbidding these structures. Such minor forms of disobedience formed the basis of a continuous antagonistic relationship between estate authorities and estate residents.

Although many poorer residents found themselves fighting for their lifestyle within the housing estates, more simply found themselves excluded altogether. Marris noted that, even in Surulere's first years, the estate was drawing and keeping only certain kinds of Lagosians. "From a predominantly Muslim, Yoruba, middle-aged community of traders and independent craftsmen," he noted, "it attracted above all the employees of Government and commercial firms, men from the Eastern Region whose close family ties in Lagos were few, the young rebel escaping from a domineering family" (1962:100). Marris also noted that the typical resident of Surulere was significantly more prosperous and Westernoriented than the typical Lagosian. In general, it seems that the government estates, although they explicitly targeted low-income Lagosians, tended to bring in only certain portions of the population. Oberu Aribiah (1974:42) expressed the worry that low-income housing schemes would cater to "employees of governments and sometimes industry while leaving out those sections of the population, who, though equally poor, are self-employed as petty traders, wayside mechanics, and such other occupations."

Noting the self-selection among residents of government estates, private construction firms in Nigeria began to construct similar housing flats. These they rented out - blocks of flats at a time with rent paid five years in advance - to industries and embassies for the housing of senior staff members (Aribiah 1974:41). But with both government and private estates meeting the needs of officials and professionals, working-class Lagosians were again left out on their ears. Various declarations by the government that the LEDB and its successor, the Lagos State Property Development Corporation, should be self-financing further committed the agencies to a policy of housing only those Lagosians who could pay the market price. In its attempts to house slum dwellers and turn them into polite suburbanites, the government more often found that those very slum dwellers would slip, like fine sand, through its fingers.

\section{Slums and Indiscipline}


The shift from colonial to postcolonial governance meant a new scope for the state, which was now to represent the entire populace, not just imperial interests. The supply of government-provided housing and infrastructure rose to meet that new demand, but only very feebly. Despite a widely acknowledged need for more housing in Lagos, in 1979, after a spate of government construction, it was still the case that for every house owned by the government, there were at least one hundred privately owned houses (Peil 1991:145). Even urban planning fell short; a quickly urbanizing population meant that the proportion of Lagosians living in unplanned areas actually rose after independence-from $22 \%$ in 1952 to 50\% in 1973 (Jawando and Vander Zee 1985:340).

The prime explanation of the failure of Lagos to provide adequate housing is simply the sheer size of the housing problem. From the $1950 \mathrm{~s}$ onward, overcrowding became the salient feature of life in Lagos. As of $1972-73$, the city boasted an average of 4.4 persons per room, with $76.4 \%$ of households living entirely in one room, more crowded than any other Nigerian town or city (see Olu Sule 1978:67-85). The most crowded areas, of course, were and are the slums. In a study of five major Lagos slums in 1977, M. A. O. Ayeni found that the average number of persons per house ranged from 14.8, in Isale Eko, to 27.6, in Mushin (Ayeni 1977:78). For many slums, such overcrowding was partially compensated for by better provision of toilets, electricity, and pipe-borne water than might be found in other towns (although still not at anywhere near satisfactory levels), but for slum areas along the suburban fringe, even these amenities were lacking.

The overcrowded conditions that posed such a problem for Lagos planning authorities were in large part caused by the constant influx of out-of-state migrants to Lagos in search of jobs. Like so many African countries, Nigeria structured its economic development plans in favor of industry rather than agriculture. Nigeria's population grew faster than its agricultural sector did, pushing rural Nigerians into the cities. And yet, in a labor-intensive, low-capital economy such as Nigeria's, there were few good jobs to be had. The volatile oil market of the 1970s exacerbated the problem by creating a number of jobs, drawing in Ghanaians as well as out-of-state Nigerians, only to destroy them soon after as the oil bubble burst. By 1978, about three-quarters of migrants to Lagos had come to find employment (Agbola 1997:49). These transient migrants settled by and large in slums, both for lack of money and because, according to Awotona (1981:166), they "would rather invest in a house in their village or 'home-town' than in Lagos." Slum areas like Idi-Araba and OlaleyeIponri village were overwhelmingly populated with those born outside of Lagos (Aina 1990:92; Awotona 1993:130).

The houses of unplanned residential communities could not have been more different from those of government estates. Crowded together and lacking modern amenities, they were ramshackle constructions, often built piecemeal by the owners or tenants themselves. Unlike government 
houses and apartments, they did not imitate British colonial models. Nor, for that matter, did they resemble precolonial mud compounds. If they can be said to have had any model, it was the Brazilian-style bungalows brought to Nigeria from Brazil by Muslim and Catholic ex-slaves resettled by the Portuguese in Lagos in the latter half of the nineteenth century (Hallen 1988). These bungalows featured a central corridor with facing rooms on either side and external bathrooms and kitchens, and many in Lagos also included ornamental frills and bright colors imported from Brazil as well (Mabogunje 1968:119; Akinsemoyin and VaughanRichards 1976:62). The Brazilian building type was particularly popular among Yorubas, for whom the central corridor was used as a sort of reduced internal courtyard. In his survey of Lagos slums, Tade Akin Aina (1989:409) discovered that these units accounted for 61\% of dwellings in Iponri, $62 \%$ in Olaleye, $72 \%$ in Old Makoko, and 75\% in New Makoko.

Poorer Lagosians did not just build differently than the government did, they also used space differently as well. Lagosian Yorubas, for example, modernized and urbanized ritual, so that at a naming or burial ceremony, houses in the neighborhood would be commandeered and traffic blocked off to make room for dancing (Onajide 1988:5). In slums, Awotona (1993:137) found, residents would use space in ways that might be confounding to a European observer.

A high degree of permeability between the dwelling units and surroundings was the rule. The residents used the street, or adjoining public space, as a living space, part of their territory, and were "at home" there. All the channels between the individual dwelling unit and environment, such as the doors, windows, etc., were frequently and vigorously used as a bridge between the inside and outside. . . . "Home" was therefore not just the dwelling unit but a whole local region in which the households experienced some of the most meaningful aspects of their lives.

Even the houses themselves took on meanings within the community as various stages in house-construction were often marked by rituals, sacrifice, and feasting (Aina 1988:44).

Not surprisingly, these unplanned residential areas had close connections to the informal economy. In his study of Olaleye-Iponri, Aina (1990:92) found that "economic life in the settlement is dominated by what has been called either the 'informal sector' or petty commodity production." In another study (1989:402), he found the same to be true for Makoko as well. Margaret Peil's 1981 study of Ajegunle found that over a quarter of men and just under three-quarters of women earned their primary wages through self-employment (Peil 1981:95). That figure does not include those working only part time in the informal sector or those working informally but under the employ of another. And yet the activities of the informal economy were not limited to the slums, but 
could be found in every part of the metropolitan area-rich or poor (Fapohunda 1985:33).

Although Lagosian slums fell outside of the purview of government provision, they were not outside of government control altogether. Indeed, independence meant that the laws formerly applied and enforced only in select European areas were expanded, both on paper and in practice, to apply to all of Lagos. These laws themselves, however, were often colonial holdovers ill-suited for a capital city in independent Africa. As a result, conflicts between legal ideals and on-the-ground realitiesignored by the colonial state-were all too readily apparent in postcolonial Lagos. The effect of subjecting a burgeoning independent metropolis to outdated colonial laws was to make law-breakers of the entire population. Extra-legality had been transformed into illegality.

The most important set of laws with regard to Lagosian slums were, of course, building regulations. Rules specifying minimum standards for house, space between buildings, and wall thickness embodied British colonial notions of respectability and hygiene-often copied directly from English municipal legislation - that were simply unattainable in the Lagosian economy. The unfortunate result of these standards was to put legal housing out of reach for the urban poor, who resorted instead to squatter settlements and illegal building, which, consequently, could be legally demolished by the government (Agbola 1994:93). The constant lack of compliance to building regulations in slum areas has been amply documented. After making his surveys, Aina (1989:406) concluded that "land use in both Olaleye-Iponri and Makoko is mixed and unaffected to any great extent by the existing formal regulations. The settlements combine commercial, residential, religious, educational and even smallscale industrial use at all levels." Similarly, Awotona's study of IdiAraba (1981:268) found the entire slum to be in violation of planning laws, with $87 \%$ of the buildings in breach of the law concerning plot coverage alone.

A city full of houses that fell in breach of the law might not in itself have been a problem for the Lagos government. There were certainly periods, particularly in the 1960s and early 1970s, when enforcement of laws concerning the shape and use of urban space was conspicuously lax. Nevertheless, the existence of such unrealistic laws meant that the government could, at any time, effectively declare war on almost any part of the city. And as the federal government pulled out of Lagos for cooler climes in Abuja and violent crime in Lagos soared in the 1980s, it did just that - enforcing its draconian laws with active policing and aggressive intervention in everyday affairs.

Often, police strikes against illegal or otherwise "undesirable" behavior amounted to little more than quick and ineffective patches for enduring problems - clearing the streets of vagrants before major festivals, for example. But even ineffectual action could have painful consequences for Lagosians. In the late 1970s, for instance, urban administrators attempt- 
ing to cut down on traffic in the city declared that only cars bearing license plates beginning with an odd number could enter the municipal area on certain days of the week (other days of the week were reserved for even-numbered cars). Not surprisingly, that ham-fisted solution was no solution at all. "Because there is no efficient mass-transit system," wrote Bola Ayeni (1981:144), "this edict has inflicted hardship on some car owners, while many families who can afford to do so have reacted by buying a second car, so as to have cars with both even and odd initial numbers in their registrations."

The apex of state crackdown on illegal or otherwise "undesirable" behavior was reached under Muhammadu Buhari's military government, from 1983 to 1985. Buhari is known for his curtailments of Nigerian civil liberties and numerous prosecutions of government officials, but it should be noted that his attempts to control the country included, as a major component, an aggressive policing of urban space. The centerpiece of that project was Buhari's War Against Indiscipline, begun in 1984. Equating "undisciplined" street life with unpatriotic sentiment, the War Against Indiscipline was a campaign to rid the country of its informal sector entirely by bulldozing slums, raiding markets, and training Nigerians to queue patiently at bus stops, shops, and government offices (Osaghae 1998:182). Between 1985 and 1986, the Lagos government reported demolishing 4,838 illegal structures-punishment for what the Commissioner for Works and Transport complained of as an "utter disregard" for building regulations (quoted in West Africa 1986: 747). The Lagos State Government's Street Trading and Illegal Markets Edict of 1984 stipulated harsh penalties for illegal trading, including a fine of one thousand naira plus three months imprisonment with hard labour for a third offense (Oloko 1991:12-13). A reporter's account of the commonly occurring scene of a police raid on an informal market gives a good sense of what these policing actions looked like on the ground:

I am walking in Balogun, the street market, on Lagos Island. Two C20 Volkswagen buses filled with police come slowly down the street followed by an open-backed lorry. Small shack owners and others selling out of baskets or off trays dive for cover, hiding their wares under benches or in gutters and stroll away, pictures of studied indifference. ... There are shouts, batons wave above the heads in the fracas and a chain of blue-shirted men starts passing goods back to the lorry. Shirts, shoes, leather belts and other clothing pile up, joining sacks (contents unknown) and other goods in the back. Then, as suddenly as they arrived, the visitors are back in their vehicles and rolling off down the road. The informal sector picks itself up, reorders its headtie, reties its wrapper, retrieves its goods from the hiding places and carries on selling (Conconbility Jane 1984:2514). 
In the eyes of many Lagosians, these police raids were not preventing anti-social behavior, but rather striking at the heart of Lagosian society.

Another important aspect of the War Against Indiscipline was the offshoot program called the War Against Filth, which required all Lagosians to remain in their homes between 7 and 10 a.m. on the last Saturday of every month in order to clean their homes and yards. The problem with that campaign, however, was that the Lagos municipal authorities funded house-to-house garbage collection in upscale, low-density residential areas only. Residents of slums and high-density areas were expected to transport their own waste (Ayeni 1981:138). Predictably, the War Against Filth led to a cleaner environment for the rich but only tighter discipline for the poor. In fact, the municipal authorities moved the trash they collected from the rich into poorer communities, where it served as swamp infill for land reclamation projects in peripheral areas such as Akoko, Ajegunle, and Ijora. At best, these projects added some land, and considerable stench. At worst, as in Ijora, the refuse failed to settle and became a serious danger to those living near it (Peil 1991:189). At the same time, the significant contribution to pollution made by Lagos industries went relatively unchecked. A few years after the War Against Filth began, the Ministry of Environment and Physical Planning estimated that only three percent of Lagos industrial firms had actually made arrangements for handling their own waste; many just dumped it wherever they found it convenient to do so (Peil 1991:189; Amdii 1993:270 271). It is not hard to see the War Against Filth, as one commentator (Amdii 1993:271) later did, as simply "an elitist programme to serve the interest of the better classed urban dwellers."

\section{The Retreat to Abuja}

As I have argued, the few decades after independence were a time of hope in Lagos and Nigeria, a time when it seemed that the government might succeed in creating a new identity for itself through architecture and urban planning. Prestige buildings in the tropical modernist style would signal the country's independence and housing estates built to resemble British towns would signal its economic strength. And yet, as battles over the War Against Indiscipline attest, shaping and sanitizing a major international city was not and could never be such a simple task.

The most telling emblem of the failure of officials and elites to get the Lagos they wanted is the establishment of Abuja, a new federal capital hundreds of miles from the coast, planned along the lines of other highmodernist cities in the Third World like Chandigarh and Brasília. ${ }^{3}$ The removal of the capital from Lagos had been on the table well before independence even. Lord Lugard advocated moving the capital to Kaduna, both because it was more central and because it would allow the British

\footnotetext{
${ }^{3}$ For an excellent analysis of those high-modernist cities, see Scott 1998: chap. 4. The discussion of Abuja in this article is entirely compatible with Scott's description of high-modernist cities in general.
} 
to spread their influence north. Postcolonial presidents Nnamdi Azikiwe and General Yakubu Gowon toyed with the idea of a move away from Lagos as well. It was not until 1975, however, when the government's revenues were inflated by petrodollars, that General Murtala Muhammed and the Supreme Military Council unanimously decided to transfer the capital (Moore 1984:168-170). Shortly after coming to power, Muhammed convened a Committee on the Location of the Federal Capital to assess the desirability of a new capital. The Committee criticized Lagos heavily as "one of the dirtiest capitals in the world," suffering from "perennial stench," and "clearly unsuitable to play the dual role of the capital of the Federation and the capital of Lagos State" (quoted in West Africa 1976:522). The Committee also explained that a new capital would enhance interior development, more evenly distribute federal spending, develop an indigenous building industry, demonstrate Nigeria's stability in the aftermath of the 1967-1970 civil war, and even improve national security by moving the capital away from the vulnerable coast (Elleh 2002:239 and Azikiwe 1974:5). More than anything, though, the barely populated area of Abuja was a blank slate, a chance to start over.

Starting over, however, meant revising some of the ideals that had governed the construction of the Lagos Marina. Abuja's government buildings, designed by Le Corbusier's student Kenzo Tange, replaced the climate-sensitive, open style of tropical modernism with a gleaming, airconditioned corporate modernism that would not have looked out of place in London, New York, or Tokyo. The inspiration for Abuja's National Mall did not come from any indigenous form, but rather from Washington D.C. A few buildings within Abuja, most notably the Conference Centre by Towry-Coker Associates, sought to present "a distinctive Nigerian flavour," but for the most parts the hotels and government offices in Abuja were modeled after corporate buildings in the United States and Europe (Courtney-Fitch 1983:23).

By necessity, much of the Abuja scheme consisted of residential units to house the numerous governmental workers (as well as those employed in the ongoing process of building Abuja). The dwellings themselves were based almost exclusively on the British New Town model, with few concessions made to the demands of culture or climate. "I am convinced," wrote an observer, "that much of Abuja's residential and shopping plans rubbed off from a visit by a high-powered Nigerian government team to Milton Keynes, one of Britain's New Towns" (CourtneyFitch 1983:18). In fact, Conran Roche, the architectural firm behind Milton Keynes, had been hired by the Nigerian government to plan the shopping area for Abuja. But just as they had in exurban Lagosian estates, European models in Abuja fell flat. As one architect working on the project complained: 
Dwellings have no family spaces to suit African or Islamic life styles: there are no private outside spaces essential for life in Africa and vital for low income families to upgrade family income/standards, for example by keeping chickens and growing small crops. There is no space to keep refuse out of doors. There is nowhere for children to play out of doors away from roads but within sight of the house. There are no places to hang clothes to dry. In a hot, humid climate washing clothes is a continuous process in family life. Perhaps the British designers imagined fitted kitchens with washing machines and tumble driers (Architect's Journal 1985:71-74).

On the other end of the spectrum, six- and seven-bedroom luxury villas for government officials continued the legacy of colonial segregation. According to architectural historian Nnamdi Elleh (1997:326), “Abuja has already cast a line between housing for the poor and housing for the rich and powerful. Housing segregation by status is an inherent part of the master plan."

Segregation between various classes of housing was less of a problem than segregation between those with housing and those left to fend for themselves entirely. According to the government plan, no "temporary" workers' camps would be allowed, and all workers would be housed. "It is impossible for slums to develop here in Abuja," declared Hamza Abdullahi, Minister for the Federal Capital Territory, in 1978. "Every inch of the city has been predetermined. . . There is absolutely no room for anyone to just start building sub-standard structures. It is impossible" (quoted in Vale 1992:147). And yet, despite official plans and protests, the high price of housing within Abuja forced construction workers and low-level civil servants to put up shantytowns and slums just outside of the planned territory and along the side of the city's main highways (Courtney-Fitch 1983:18). The attention paid to carefully planned areas and deliberate ignorance of their economically inevitable counterparts was a tidy encore of colonial administration in Government Residential Areas. Abuja, rather than solving the problems of Lagos, merely replicated them a few hundred miles north.

As it slowly moved its offices from Lagos to Abuja, the federal government became less invested in Lagos's upkeep. Simultaneously, the Babangida administration instituted an IMF-backed Structural Adjustment Program (SAP) meant to coordinate Nigeria's economic policies with the demands of the global market. The twin effect of these was devastating to Lagos. Under SAP, cities across Nigeria suffered from a decrease in public services such as transportation and housing, with the poor, predictably, bearing the brunt of the burden (Bello-Imam 1994:2:273). The double effect of the oil boom and the ending of subsidies in the city had inflated prices in Lagos considerably, often putting goods out of reach of the urban poor. Taking 1975 as zero, the Cost of Living Index had risen to 1107 by the end of 1989 (Peil 1991:101). All 
in all, that increase in prices led to a greater polarization of wealth in Lagos - a trend with palpable spatial consequences. "What made the hardship more difficult for Lagosians," observed sociologist Jinmi Adisa (1994:1:167), "was a wave of affluence that cut across the social divide. Cocaine dealers, 419 scam artists [Nigerians who make a living from email confidence games] and government officials were putting up lavish mansions in Victoria Island Annex, Ikoyi and its environs, and driving around in expensive automobiles." In effect, the residential apartheid separating the Government Residential Areas from the rest of the city had been supplanted by an equally stark apartheid, separating the poor from the super-rich.

Besides cutting employment and government provisions, SAP also presented a particular danger to Nigerian cities by increasing urban violence. After the introduction of SAP in 1986, wrote historian Esogha E. Osaghae (1998:206), "no year passed without some violent riot, strike or demonstration." In Lagos, these riots visited the city in May 1989, lasting two weeks and killing around fifty; another outbreak of rioting visited the city in 1993. A contraction of the labor market pushed a number of Lagosians into crime, and the mid-1980s saw the birth of the "Area Boys" (a violent Lagos gang culture) as well as an increase in drug trafficking (Omitogun 1994:2:203). Although rich Lagosians could protect themselves by moving to low-density neighborhoods patrolled by security officers, hawkers, particularly children, were highly vulnerable to that increase of street violence. The government by and large responded through a continuation of its policy of heavy disciplining and policing of the city, giving Lagos the highest concentration of police of any city or town in Nigeria (Nyetmutu Roberts 1994:2:382). Heavy policing has helped to protect the streets of Lagos, but it has endangered those making their living from the informal economy. In 1988 alone, 6,767 street traders were arrested and 5,049 convicted in Lagos for illegal trading (Oloko 1991:13). But at the same time as the government sought greater control of the informal sector through policing, the economic pressures of SAP pushed more and more Lagosians into petty trading, creating, according to Adisa (1994:1:161), "a situation where reserved open spaces and even sidewalks are converted into business space in Lagos." The entire city, it seems, had become a marketplace.

\section{Conclusion}

After colonialism, the Nigerian government attempted to present Lagos to the country, and to the world, as a strong, independent city, no longer a port for imperial extraction. That vision involved two aspects: architecture and provision. On the one hand, prestige government and corporate buildings used the European language of tropical modernism to distinguish independent Lagos from colonial Lagos (and thus independent Nigeria from colonial Nigeria). On the other hand, the government initiated a number of housing schemes that conveyed Nigeria's in- 
dependence by successfully imitating European models. Not only did the architecture of these housing estates resemble that of British residential areas, but the estates enforced notions of cleanliness, respectability, and appropriate behavior that had been learned through colonialism. And yet, in spite of that dual vision of modernism and modernity, Lagos was not made over as the government and architectural elites hoped. Informal trading, illegal housing, and, eventually, a rising crime wave made it clear that Lagos could not be controlled from the top-neither by reform and provision nor by authoritarian disciplinary tactics.

Failure of social control have made postcolonial cities such as Lagos difficult for historians to treat. Colonial urbanism, with its complex yet clearly demarcated relationship between colonial powers and colonial subjects, seems much easier to grasp than the postcolonial muddle. And yet, as one can see from an examination of Lagos in the decades after independence, a lack of efficacy does not imply a lack of vision. Not only can one see a coherent government interest in responding to colonialism both through symbolic distanciation as well as through an emulation of government provision, but one can also pick out a coherent resistance to that vision. Whether through throwing stones at the LEDB commissioners, writing critical articles about rehousing policies, or simply by continuing to use the street for their own purposes, a significant body of Lagosians set forth their own model for what Lagos was to be. Different both from traditional precolonial culture and from the governmentendorsed modernity of the housing estates, that ideal embodied a different sort of modernity-one steeped in the freedoms and the dangers of the urban marketplace.

Although the story of postcolonial Lagos is in many ways about the visions of Lagosians, it is also a story about the lack of choice and the restriction of vision. When setting forth its own architectural identity, the Nigerian government did not have the option of developing a new architectural language. The few major Nigerian architects who did practice in Lagos were all trained in London. Similarly, the culture of the informal economy and the illegal city were shaped by Lagosians, but not chosen by them. It was the continuation of colonial economic patterns that made Lagos a rapidly urbanizing, low-capital city. The pas de deux danced by the government and Lagosians was set to the music of an enduring legacy of colonialism.

\section{References}

Abu-Lughod, Janet L. 1980. Rabat: Urban Apartheid in Morocco. Princeton: Princeton University Press.

Adegite, E. O. 1996. "Women and Access to Housing Finance." In Women and Housing in Nigeria: Issues, Problems and Prospects, ed. Jadesola Akande, E. O. Adegite, and K. Awosika, 39-51. Lagos: Women, Law and Development Centre. 
Adisa, Jinmi. 1994. "Urban Violence in Lagos." In Urban Violence in Africa, Pilot Studies, ed. Eghosa E. Osaghae, 1:139-175. Ibadan: IFRA.

Agbola, Tunde. 1994. "The Politics and Administration of Housing Standards and the Structure of Nigerian Cities." In Urban Management and Urban Violence in Africa, ed. Isaac Olawale Albert, Jinmi Adisa, Tunde Agbola, and G. Hérault, 1:87-102. Ibadan: IFRA.

- 1997. The Architecture of Fear: Urban Design and Construction Response to Urban Violence in Lagos, Nigeria. Ibadan: IFRA.

Aina, Tade Akin. 1988. "The Construction of Housing for the Urban Poor of Lagos." Habitat International 12:31-48.

- 1989. "Popular Settlements in Metropolitan Lagos, Nigeria: A Socio-Economic and Structural Survey of the Habitat of the Urban Poor." Third World Planning Review 11:393-415.

- 1990. "Petty Landlords and Poor Tenants in a Low-Income Set tlement in Metropolitan Lagos, Nigeria." In Housing Africa's Urban Poor, ed. Philip Amis and Peter Lloyd, 87-101. Manchester: Manchester University Press.

Akinsemoyin, Kunle and Alan Vaughan-Richards. 1976. Building Lagos, 2d ed. Jersey: Pengrail.

Amdii, I. E. S. 1993. Analysis of Governmental Housing Policy in Nigeria. Zaria: Ahmadu Bello Press.

Apter, Andrew. 2005. The Pan-African Nation: Oil and the Spectacle of Culture in Nigeria. Chicago: University of Chicago Press.

Architect's Journal. 1985. "Capital Folly of Nigeria," (20 November): 69-74.

Aribiah, Oberu. 1974. “The Politics of Rehousing." Lagos Notes and Records 5:5-13

Awotona, Adenrele Ayodele. 1981. "Formal and Informal Housing in Metropolitan Lagos: A Study of User Needs, Programmes and Policy.” Ph.D. diss., Christ's College, Cambridge.

-1993. "The Urban Poor's Perception of Housing Conditions." In Urban Development in Nigeria: Planning, Housing and Land Policy, ed. Robert W. Taylor, 130-144. Aldershot: Avebury.

Ayeni, Bola. 1981. "Lagos." In Problems and Planning in Third World Cities, ed. Michael Pacione, 127-155. London: Croom Helm.

Ayeni, M. A. O. 1977. "Living Conditions of the Poor in Lagos." Ekistics 43:77-80.

Azikiwe, Nnamdi. 1974. Dialogue on a New Capital for Nigeria. Zaria: Ahmadu Bello University Press.

Bello-Imam, I. B. 1994. "Urban Problems in Nigeria: The Political Impact of Structural Adjustment Programmes on Health, Transport, and Education." In Urban Management and Urban Violence in Afri$c a$, ed. Isaac Olawale Albert, Jinmi Adisa, Tunde Agbola, and G. Hérault, 2:269-278. Ibadan: IFRA. 
Çelik, Zeynep. 1997. Urban Forms and Colonial Confrontations: Al giers under French Rule. Berkeley: University of California Press.

Conconbility Jane [pseud.]. 1984. "Common Essentialities." West Africa, 10 December, 2513-2514.

Courtney-Fitch, Bruce. 1983. "Abuja: A Focal Point for African Unity." West African Construction (February/March): 8-28.

Elleh, Nnamdi. 1997. African Architecture: Evolution and Transformation. New York: McGraw-Hill.

—. 2002. "Architecture and Nationalism in Africa, 1945-1994." In The Short Century: Independence and Liberation Movements in Africa, 1945-1994, ed. Okwui Enwezor, 234-245. Munich: Prestel.

Fapohunda, Olanrewaju J. 1985. The Informal Sector of Lagos: An Inquiry into Urban Poverty and Employment. Lagos: University Press Limited.

Federal Republic of Nigeria. 1968. Report of the Tribunal of Inquiry into the Affairs of the Lagos Executive Development Board for the Period 1st October, 1960 to 31st December, 1965. Lagos: Federal Ministry of Information.

Fishman, Robert. 1999. Urban Utopias in the Twentieth Century: Ebenezer Howard, Frank Lloyd Wright, Le Corbusier. Cambridge, Mass.: The MIT Press.

Fry, Maxwell. 1962. "Tropical Architecture: The Development of Reinforced Concrete in West Africa." West African Builder and Architect (March/April): 27-31.

- and Jane Drew. 1964. Tropical Architecture in the Dry and Humid Zones. London: B. T. Batsford.

Grillo, Y. 1968. "Art in Architecture in Nigeria." West African Builder and Architect (January/February): 3-5.

Hallen, Barry. 1988. "Afro-Brazilian Mosques in West Africa." Mimar 29 (September): 16-23.

Home, Robert K. 1983. "Town Planning, Segregation and Indirect Rule in Colonial Nigeria." Third World Planning Review 5:165-176.

James, Akpan. 1959. "Rebuilding Nigeria's Capital." West African Review 30 (1959): 8-10.

Jawando, O. A. and J. Vander Zee, 1985. "Upgrading of Unplanned Urban Development." In Housing in Nigeria: A Book of Readings, ed., Adepoju Onibokun, 339-355. Ibadan: NISER.

King, Anthony D. 1976. Colonial Urban Development: Culture, Social Power, and Environment. London: Routledge \& Kegan Paul.

-1990. Urbanism, Colonialism, and the World-Economy: Cultural and Spatial Foundations of the World Urban System. London: Routledge.

Koenigsberger, Otto. 1974. Manual of Tropical Housing and Design. London.

Koolhaas, Rem. 2001. Mutations. Bordeaux: Arc En Rêve Centre d'Architecture. 
Krapf-Askari, Eva. 1969. Yoruba Towns and Cities: An Enquiry into the Nature of Urban Social Phenomena. Oxford: Clarendon Press.

Lagos Executive Development Board. 1961. Annual Report and Accounts, 1960-1961.

- 1963. Annual Report and Accounts, 1962-1963.

Le Roux, Hannah. 2004a. "Building on the Boundary-Modern Architecture in the Tropics." Social Identities 10:439-453.

. 2004b. "Modern Architecture in Post-Colonial Ghana and Nigeria." Architectural History 47:361-392.

- 2003. "The Networks of Tropical Architecture." The Journal of Architecture 8:337-354.

Mabogunje, Akin L. 1968. Urbanization in Nigeria. London: University of London Press.

Mark, Percy. 1964. "Thoughts on Building in Tropical Africa." West African Builder and Architect (May/June): 52-53.

Marris, Peter. 1962. Family and Social Change in an African City: A Study of Rehousing in Lagos. Chicago: Northwestern University Press.

Moore, Jonathan. 1984. "The Political History of Nigeria's New Capital." Journal of Modern African Studies 22:167-175.

Nevanlinna, Anja Kervanto. 1996. Interpreting Nairobi: The Cultural Study of Built Forms. Helsinki: Suomen Historiallinen Seura.

Nyetmutu Roberts, F. O. "Metropolis under Stress: The Political Sociology of Structural Adjustment and Urban Violence in Lagos, Nigeria." In Urban Management and Urban Violence in Africa, ed. Isaac Olawale Albert, Jinmi Adisa, Tunde Agbola, and G. Hérault, 2:377-389. Ibadan: IFRA.

Oloko, Beatrice Adenike. 1991. "Children's Work in Urban Nigeria: A Case Study of Young Lagos Street Traders." Protecting Working Children, ed. William E. Myers, 11-23. London: Zed Books.

Olu Sule, R. A. 1978. "An Assessment of Nigerian Housing Allocation Policy." African Urban Studies 1:67-85.

Okoye, T. O. 1990. "Historical Development of Nigerian Housing Policies with Special Reference to Housing the Urban Poor." In Housing Africa's Urban Poor, ed. Philip Amis and Peter Lloyd, 73-85.

Manchester: Manchester University Press.

Omitogun, Wuyi. 1994. "The Area Boys of Lagos: A Study of Organized Street Violence." In Urban Management and Urban Violence in Africa, ed. Isaac Olawale Albert, Jinmi Adisa, Tunde Agbola, and G. Hérault, 2:201-208. Ibadan: IFRA.

Onajide, M. O. 1988. The Development of Housing Policy in Nigeria, 1952-1983: A Case Study of Western Nigeria. Abuja: National Library of Nigeria.

Osaghae, Eghosa E. 1998. Crippled Giant: Nigeria since Independence. Bloomington: Indiana University Press.

Peil, Margaret. 1981. Cities and Suburbs: Urban Life in West Africa. 
New York: Holmes and Meier.

- 1991. Lagos: The City is the People. London: Belhaven Press.

Scott, James C. 1998. Seeing Like State: How Certain Schemes to

Improve the Human Condition Have Failed. New Haven: Yale University Press.

Vale, Lawrence J. 1992. Architecture, Power, and National Identity. New Haven: Yale University Press.

Vaughan-Richards, Alan. 1967a. "Current Trends of Philosophy of Design in Modern Nigerian Architecture." West African Builder and Architect (July/August): 95-97.

—. 1967b. "The New Generation (Part II)." West African Builder and Architect (March/April): 24-49.

West Africa. 1976. "Retreat from Lagos." (19 April): 522.

. 1986. Untitled Article. (7 April): 747.

West African Builder and Architect. 1965a. "Flats for the University of Lagos, Alagbon Village, Ikoyi." (March/April): 35-40.

. 1965b. "Houses for the University of Lagos, Alagbon Village, Ikoyi." (July/August): 66-72, 82.

—. 1967. "Building Design in Nigeria." (July/August): 93-108.

Wright, Gwendolyn. 1991. The Politics of Design in French Colonial Urbanism. Chicago: University of Chicago Press.

. 2002. "The Ambiguous Modernisms of African Cities." In The Short Century: Independence and Liberation Movements in Africa, 1945-1994, ed. Okwui Enwezor, 225-233. Munich: Prestel. 